\title{
62. DINOFLAGELLATE CYSTS IN DEEP-SEA CORES FROM DSDP SITE 372, EAST MENORCA RISE
}

\author{
Domenico Corradini, Institute of Paleontology, Modena University, Italy
}

\section{INTRODUCTION}

Site $372\left(40^{\circ} 01.86^{\prime} \mathrm{N}, 04^{\circ} 47.79^{\prime} \mathrm{E}\right)$ is on the East Menorca Rise (Figure 1). The present depth of the sea floor is 2734 meters. Forty-six cores were recovered from the site; the total penetration of 885 meters.

The section penetrated includes four lithologic units: Unit I, Pliocene-Quaternary nannofossil marls; Unit II, upper Miocene gypsum and dolomitic marls; Unit III, lower to middle Miocene nannofossil marls to marlstones; and Unit IV, lower Miocene mudstones to nannofossil marlstones.

Eleven samples were examined for dinoflagellate cysts from Cores 9, 12, 28 through 35 , and 46. The transitional contact between Unit II (evaporitic unit) and Unit III (pre-evaporitic unit) occurs in Core 9. Core 12 and Cores 28 through 33 belong to Unit III (Serravallian to upper Burdigalian). This unit appears to be a transitional zone and consists mainly of nannofossil marls (the carbonate content ranges from $35 \%$ to $60 \%$ ). The remaining cores comprise Unit IV(Burdigalian), and Core 46 was taken from the bottom of the hole. Unit IV is distinguished from Unit III by its high clay content $\left(\mathrm{CaCO}_{3}\right.$ ranges from $15 \%$ to $\left.30 \%\right)$.

Samples of about 10 grams were processed by using a standard hydrofluoric acid/flotation technique and residues were mounted in glycerine jelly.

Slides have been deposited at the Institute of Paleontology, Modena University, Italy, under Catalog Nos. 18842-18930.

\section{RESULTS}

Dinoflagellate cysts are present in all samples examined, although in some cases specimens are very rare. The cysts are usually quite well preserved, particularly those found in Unit III. Specimens from Unit IV are, however, poorly preserved.

\section{Sample 9-4, 130-132 cm}

The sample from Core 9 contains only two specimens; both are Homotryblium floripes (Deflandre and Cookson).

\section{Sample 12-6, 84-86 cm}

The dinoflagellate assemblage of Core 12 is dominated by Homotryblium floripes (Deflandre and Cookson). Other dinoflagellates present include Operculodinium centrocarpum (Deflandre and Cookson) and $O$. sp., and fewer specimens of Spiniferites spp. and Leptodinium patulum Wall.

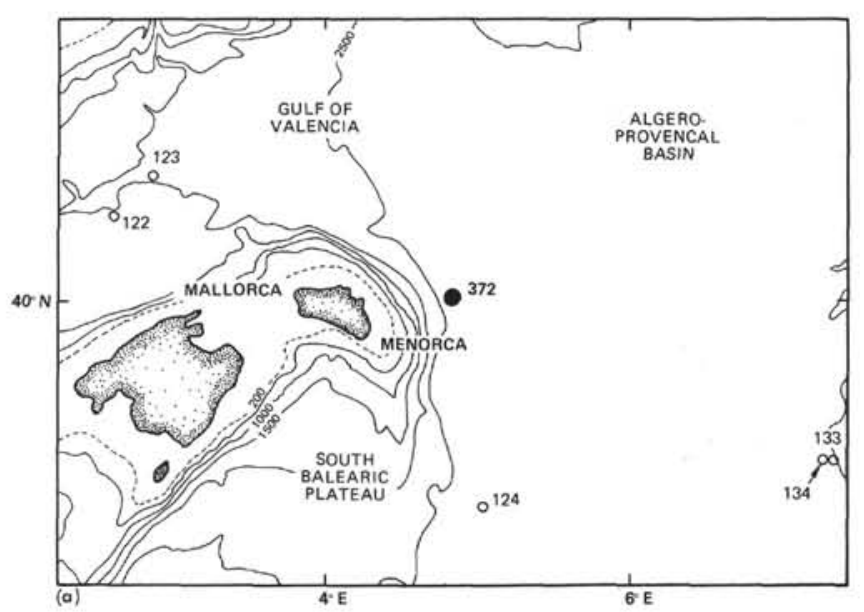

Figure 1. Location of Site 372, on the E. Menorca Rise.

\section{Sample 28-2, 25-27 cm}

A relatively rich assemblage of dinoflagellate cysts (700 specimens) occurs in this core. Individuals are generally quite well preserved. The genus Spiniferites, chiefly the species $S$. ramosus var. ramosus (Davey and Williams) and $S$. ramosus var. ind., dominates the assemblage comprising more than $60 \%$ of the specimens. Other dinoflagellates include $O$. centrocarpum, $O$. sp., Lingulodinium macherophorum (Deflandre and Cookson), Hystrichokolpoma cinctum Klumpp, H. rigaudae Deflandre and Cookson, Gonyaulacysta tenuitabulata (Gerlach). Leptodinium patulum Wall is also well represented (more than $10 \%$ ). Scattered specimens of Rottnestia borussica (Eisenack) and Cannosphaeropsis $\mathrm{sp}$. are also present. The last two taxa are restricted to Cores 28 and 29.

\section{Sample 29-2, 20-22 cm}

The dinoflagellate assemblage is very similar in taxa and number of specimens to that found in Core 28 . The principal difference is the occurrence here of forms which are probably related to the genus Systematophora. These forms were recovered throughout all studied samples from underlying sediments. Thalassiphora pelagica (Eisenack) and Tasmanites sp. (algae: Prasinophyceae) complete the assemblage.

\section{Samples 30-2, 5-7 cm, 31-2, 26-28 cm, 32-2, 8-10 cm, 33-2, 16-18 cm}

Fewer specimens were recovered in these cores than in Cores 28 and 29, but the assemblage is basically the 
same. Leptodinium patulum Wall occurred in Core 32 but not in the overlying cores. Fragments of pyritized radiolarians are fairly common in Core 30 .

\section{Samples 34-2, 13-15 cm and 35-2, 38-40 cm}

These cores contain a very poor assemblage which lacks significant forms. Operculodinium centrocarpum is present in Core 34 whereas it seemed to be absent, together with other Operculodinium spp., in Core 35. The number of individuals of the genus Spiniferites, is markedly less than in the overlying units in which Spiniferites forms a significant component.

\section{Sample 46-3, $17-23 \mathrm{~cm}$}

The assemblage in this core is relatively poor and the specimens are extremely badly preserved. Dinoflagellate cysts present include Spiniferites pseudofurcatus (Klumpp), Lingulodinium macherophorum, Hystrichokolpoma cinctum, Cleistosphaeridium cf. multifurcatum and the Prasinophyceae Tasmanites sp. and Crassosphaera concinna Cookson and Manum. Plant cuticles and other fragments are fairly common.

\section{DISCUSSION}

Insufficient data were obtained in this preliminary report to reach conclusions about the general distribution and frequency of dinoflagellate cysts in the Medi- terranean area. Moreover, very little information is available on the Miocene sediments of this area. However, some general remarks follow:

Homotryblium floripes, recovered from upper Miocene horizons in Cores 9 and 12, has been previously reported from the upper Eocene of Australia and the Oligocene of Germany.

Leptodinium patulum Wall is here first recorded from lower Miocene sediments even though it also occurs abundantly in middle Miocene samples.

Rottnestia borussica and Cannosphaeropsis sp. may have some stratigraphical significance, inasmuch as they are restricted to Cores 28 and 29.

Genera Spiniferites and Operculodinium, uncommon in the lowermost intervals (Cores $34,35,46$ ) are well represented in Cores 28 through 33.

The extremely rare occurrence of disaccate coniferal pollen grains suggests that the depositional site was reasonably far from land.

Specimens in the marls of Unit 3 are notably better preserved.

\section{ACKNOWLEDGMENTS}

I am grateful to M. B. Cita, shipboard participant on DSDP Leg 42A, for giving me the opportunity to examine the cores, to E. Montanoro Gallitelli and to E. Serpagli, Institute of Paleontology, Modena University, for their helpful discussions. 



\section{PLATE 1}

Selected dinoflagellate cysts recovered from DSDP Site 372. Magnification $\times 500$ if not specified.

Figure 1 Gonyaulacysta tenuitabulata (Gerlach). Core 28.

Figure 2 Spiniferites mirabilis (Rossignol). Core 32.

Figures 3,6 Spiniferites ramosus var. ind. Core 28.

Figures 4,5 Leptodinium patulum Wall.

4. Dorsal view.

5. Ventral surface viewed by transparency. Core 12.

Figures 7,8 Hystrichokolpoma cinctum Klumpp.

7. Apical view.

8. Antapical view. Core 28.

Figures 9,12 Homotryblium floripes (Deflandre and Cookson).

9. Epitractal archeopyle. Core 12.

Figures 10,11 Hystrichokolpoma rigaudae Deflandre and Cookson. Core 30 .

\section{PLATE 2}

Magnification $\times 500$ if not specified.

Figure 1 Operculodinium centrocarpum (Deflandre and Cookson). Core 34.

Figures 2,3 Operculodinium sp. Core 28.

Figure $4 \quad$ Form A. Core 31.

Figures 5,8 Rottnestia borussica (Eisenack).

5. Dorsal view.

8. Ventral view viewed by transparency. Core 28.

Figures 6,9 Cannosphaeropsis sp.

9. Oil immersion to show punctate surface of the central body. Core $28 . \times 1000$.

Figure $7 \quad$ ?Tectatodinium sp. Core 28.

Figures 10,12 Tasmanites sp. Core 29.

Figure 11 Crassosphaera concinna Cookson and Manum. Core 46.

(see p. 1230) 
PLATE 1
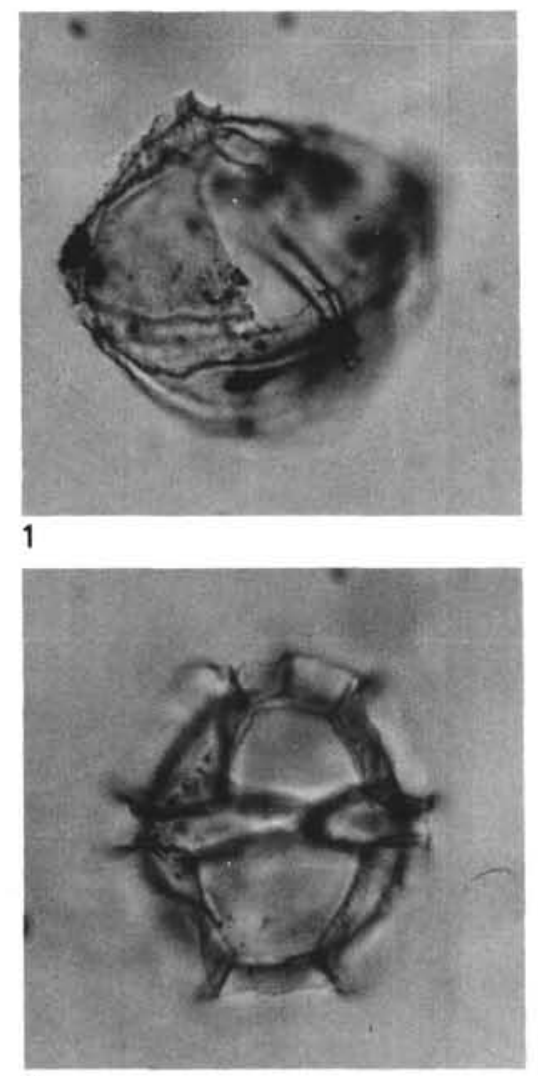

4

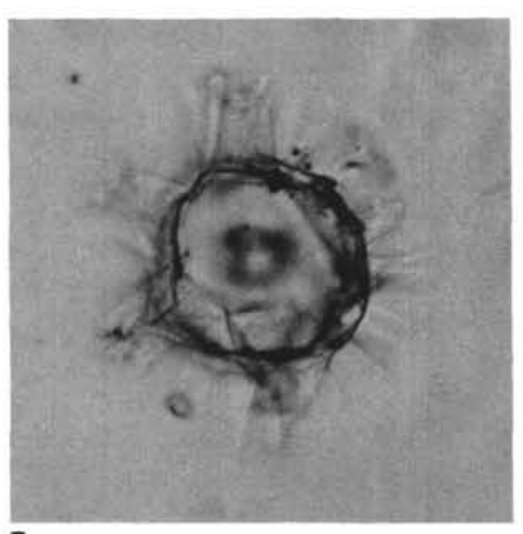

7

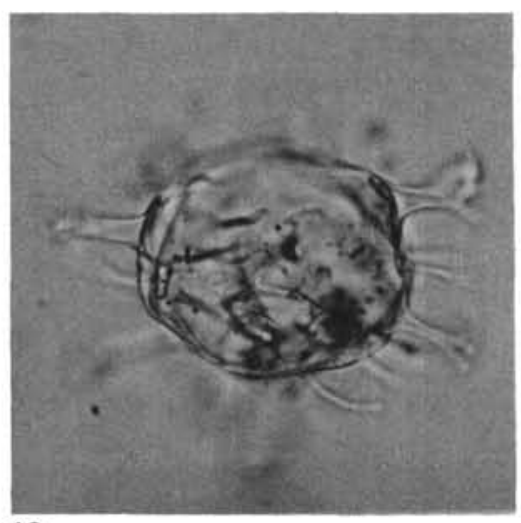

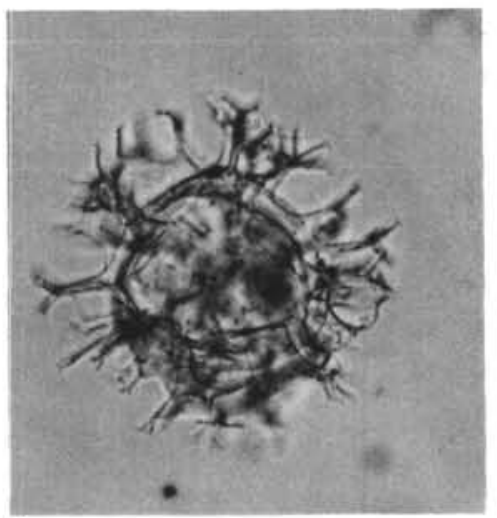
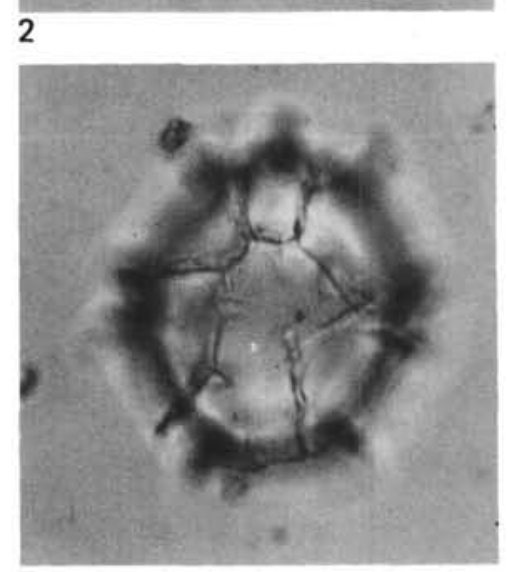

5

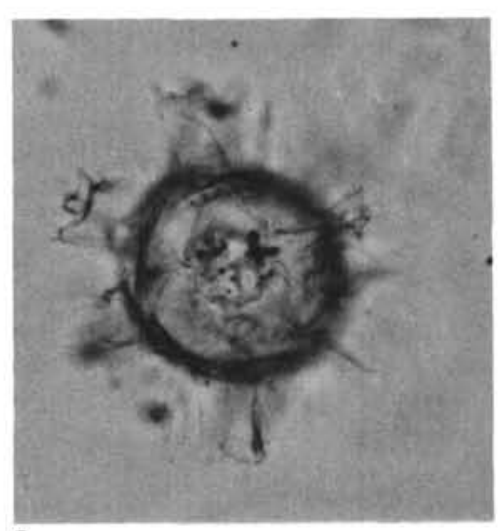

8

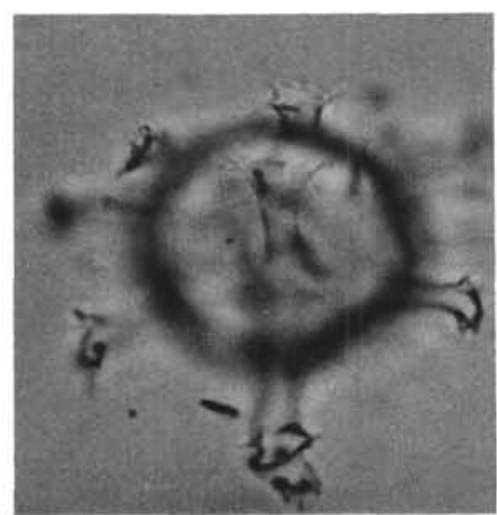

11

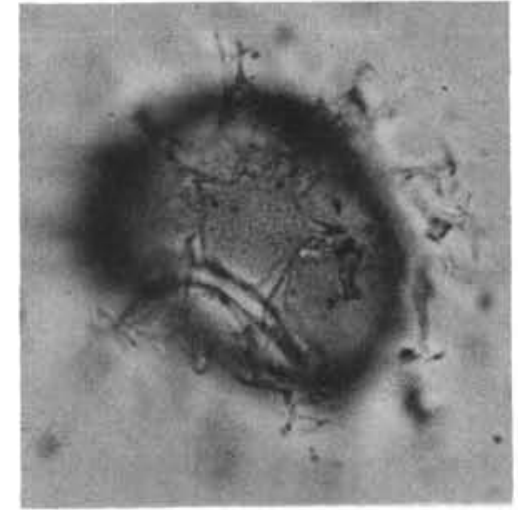

3

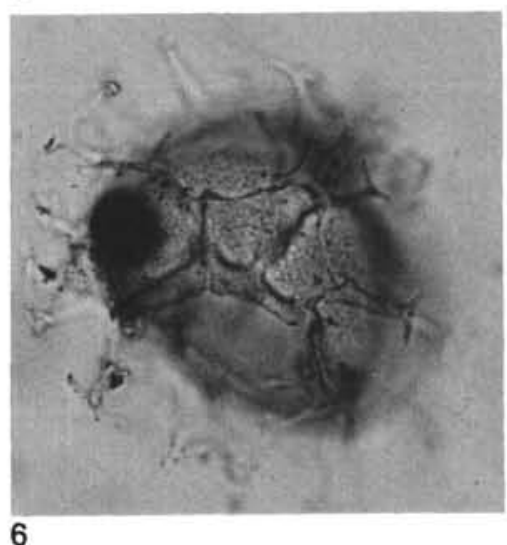

6

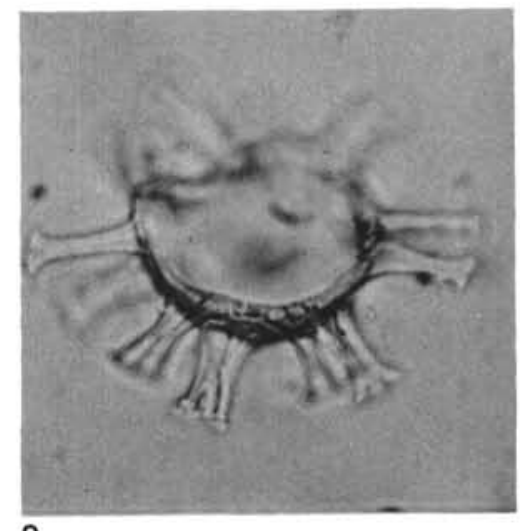

9

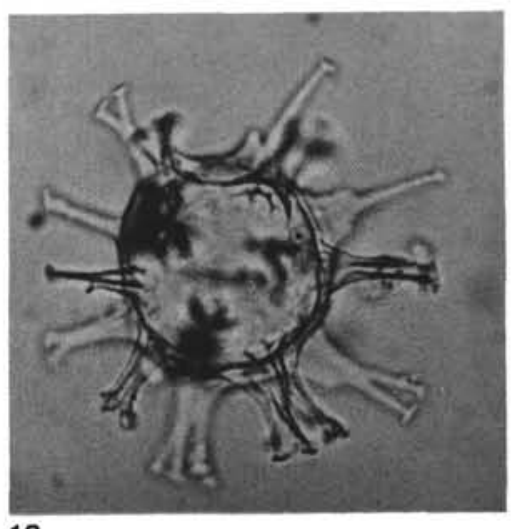


PLATE 2
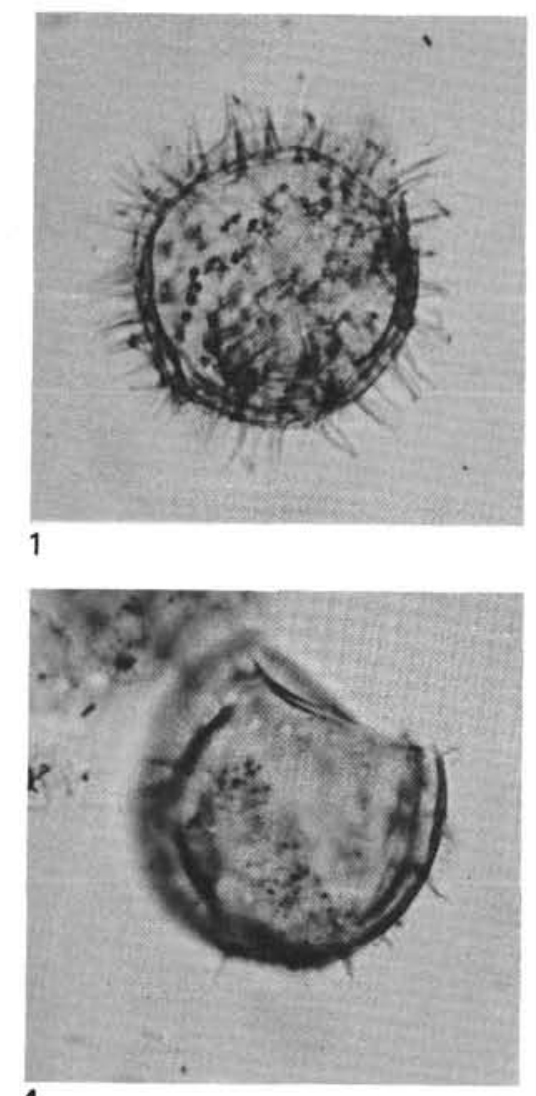

4

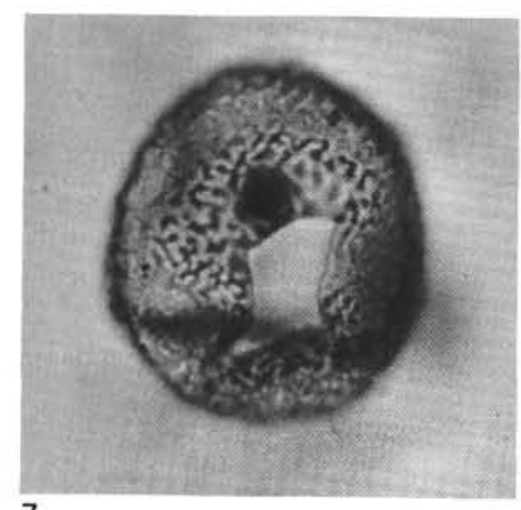

7

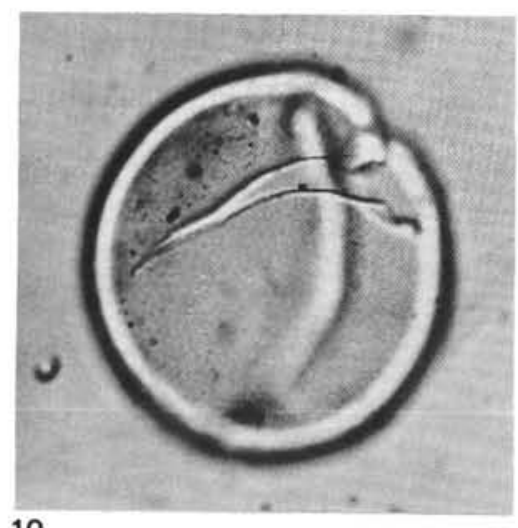

10

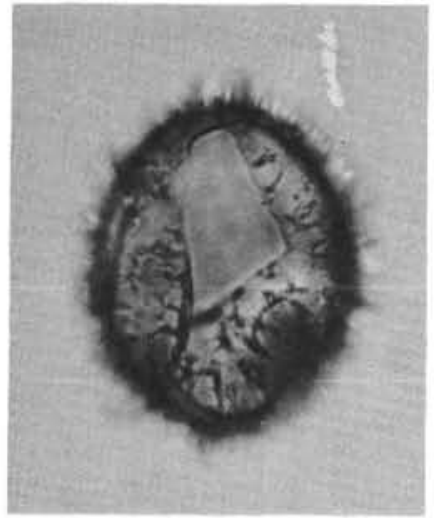

$$
2
$$

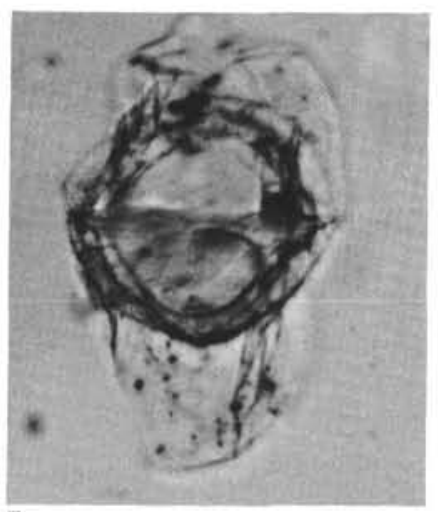

5

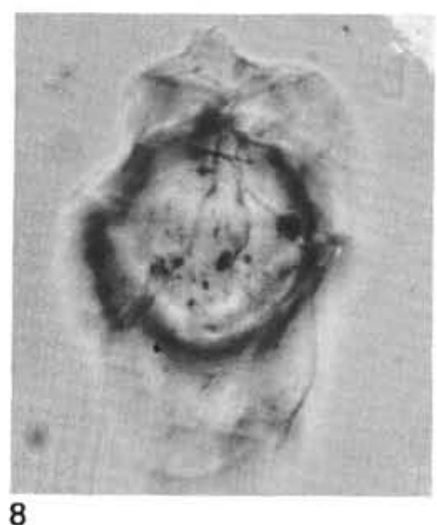

8

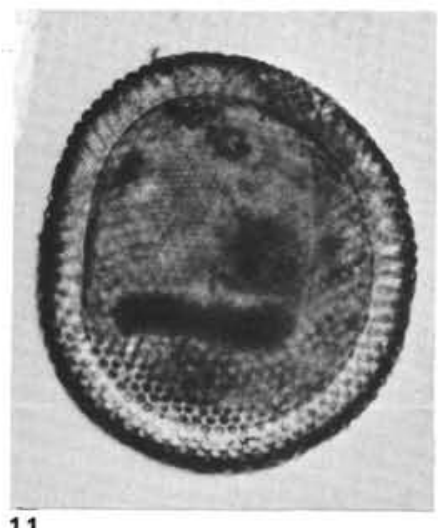

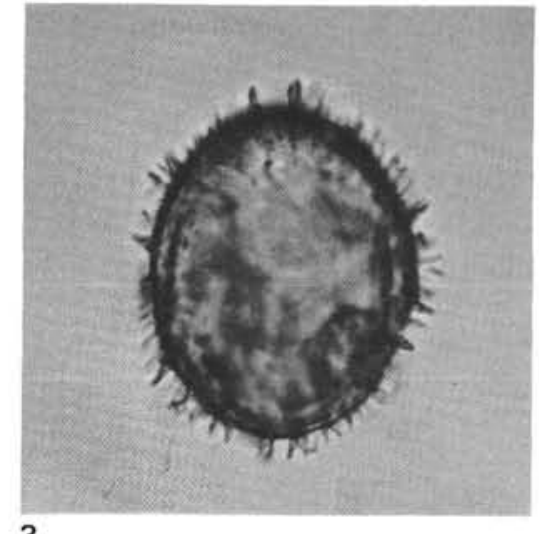

3
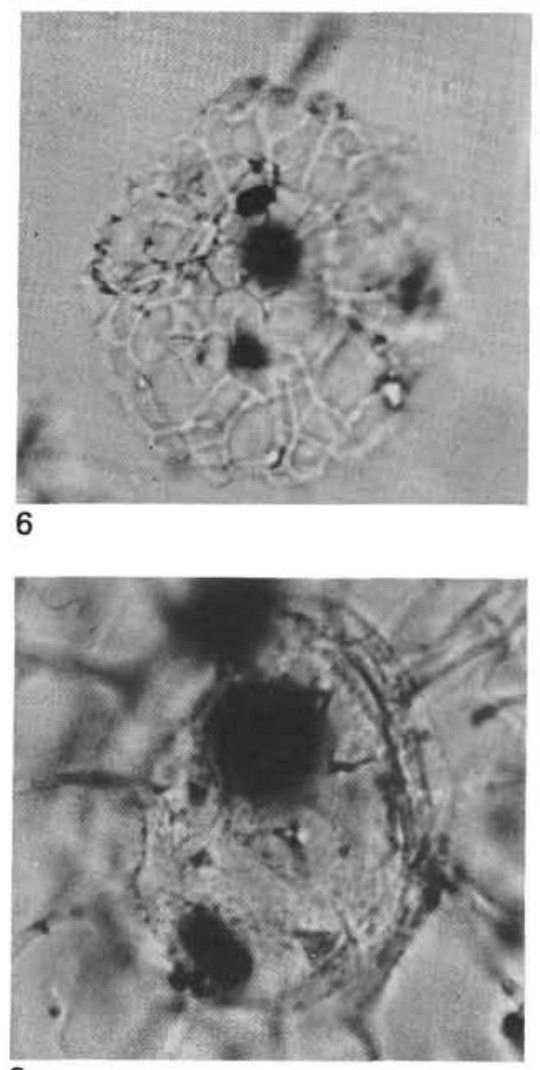

9

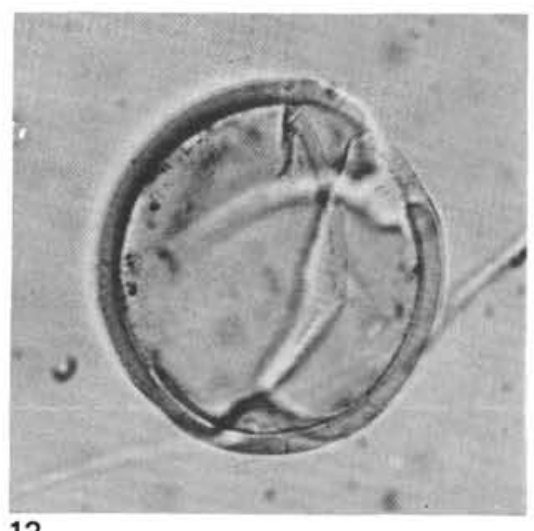

